\title{
Outcomes of Cessation of Antiviral Therapy in Chronic Hepatitis B: A Retrospective Cohort Study
}

\author{
Kronik Hepatit B Antiviral Sonlandırma Sonuçları: Retrospektif Bir Kohort \\ Çalışması
}

\author{
Pinar ERGEN $\odot$, Burcu ISIK $\odot$, Ferhat ARSLAN $\bullet$, Fatma Yilmaz KARADAG $\bullet$, Ozlem AYDIN $\bullet$, \\ Yasemin CAG $\odot$, Saadet YAZICI $\odot$, Ayse Canan UCISIK $\odot$, Mustafa Haluk VAHABOGLU $\odot$
}

Ethics Committee Approval: This study was approved by the Ethics Committee of Istanbul Medeniyet University Goztepe Training and Research Hospital. 18 September 2019, 2019/0367.

Conflict of interest: The authors declare no conflicts of interest.

Funding: None.

Informed Consent: Not applicable.
Cite as: Ergen P, Isık B, Arslan F, et al. Outcomes of cessation of antiviral therapy in chronic Hepatitis B: A retrospective cohort study. Medeni Med J. 2021;36:201-8.

\begin{abstract}
Objective: Data on the efficacy and duration of nucleos(t)ide analogue (NUC) therapies to prevent the development of cirrhosis and hepatocellular carcinoma in chronic hepatitis $B$ (CHB) patients are scarce and heterogeneous. This study aimed to summarize the clinical and laboratory results of the patients with $C H B$ infection who discontinued oral antiviral therapy.

Methods: A single-centered cohort study was conducted with CHB infection. NUCs were discontinued in patients who were under viral suppression for at least two years with undetectable $H B V D N A$ levels for 18 months. Risk factors for clinical relapse (CR) were evaluated.

Results: A total of 77 patients were recruited. $H B e A g$ status showed that $9.4 \%$ of the patients underwent $\mathrm{HBe} A \mathrm{~g}$ seroconversion with NUCs. HBeAg reversion was noted in four (31\%) of these patients. Severe hepatitis, which resolved after antiviral therapy was restored, was reported in two out of 77 patients (4\%). None of the patients with CR had clinical or biological signs of hepatic decompensation or died during the study period.

Conclusions: We found no benefits of the discontinuation of antiviral therapy after viral suppression in patients with initially severe fibrotic HBV infection. In patients with mild to moderate fibrosis, cessation of antiviral treatment is not associated with adverse outcomes.
\end{abstract}

Keywords: Chronic Hepatitis B, antiviral therapy, hepatitis B virüs

öz

Amaç: Kronik hepatit B (KHB) hastalarında siroz ve hepatoselüler karsinom gelişimini önlemek için nukleos(t)id analog (NUK) tedavilerinin etkinliği ve süresine ilişkin veriler az ve heterojendir. Bu çalışma, oral antiviral tedaviyi bırakan KHB enfeksiyonlu hastaların klinik ve laboratuvar sonuçIarını özetlemeyi amaçlamaktadır.

Yöntem: KHB enfeksiyonlu hastalarda tek merkezli bir kohort çalıșması yapılmıștır. En az iki yıldır viral baskılama altında olan ve 18 aydan beri saptanamayan HBV DNA düzeyleri olan hastalarda NUK'lar kesilmiștir. Klinik relaps (KR) için risk faktörleri değerlendirilmiștir.

Bulgular: Çalışmaya toplam 77 hasta alındı. HBeAg durumu, hastaların\% 9.4'ünün NUK'larla $\mathrm{HBeAg}$ serokonversiyonu geçirdiğini gösterdi. Bu hastaların dördünde (\%31) HBeAg reversiyonu kaydedildi. Antiviral tedavisi yeniden başlandıktan sonra düzelen şiddetli hepatit, 77 hastanın 2 'sinde (\%4) bildirilmiştir. KR'li hiçbir hastada klinik veya biyolojik hepatik dekompansasyon belirtisi görülmemiştir veya çalışma süresi boyunca ölmemiştir.

Sonuc: Bașlangıçta șiddetli fibrotik HBV enfeksiyonu olan hastalarda viral baskılamadan sonra antiviral tedavinin kesilmesinin herhangi bir faydası bulamadık. Hafif ile orta şiddette fibrozlu hastalarda, antiviral kesilme, olumsuz sonuçla ilişkili değildir.

Anahtar kelimeler: Kronik Hepatit B, antiviral tedavi, hepatit B virüs
Received: 19 April 2021

Accepted: 21 July 2021

Online First: 30 September 2021

Corresponding Author:

F. Arslan

ORCID: 0000-0001-8554-7651

Istanbul Medeniyet University Faculty of Medicine,

Department of Infectious

Diseases and Clinical Microbiology, Istanbul, Turkey

ferhatarslandr@hotmail.com

\section{P. Ergen}

ORCID: 0000-0003-3990-7956

B. Isık

ORCID: 0000-0002-0428-857X

F. Yilmaz Karadag

ORCID: 0000-0003-4657-5291

O. Aydin

ORCID: 0000-0003-0398-9216

S. Yazici

ORCID: 0000-0002-1878-3758

A.C. Ucisik

ORCID: 0000-0003-4692-3428

Istanbul Medeniyet University

Göztepe Training and Research

Hospital, Department of Infectious Diseases and Clinical Microbiology, Istanbul, Turkey

Y. Cag

ORCID: 0000-0002-9983-0308 M.H. Vahaboglu

ORCID: 0000-0001-8217-1767

Istanbul Medeniyet University Faculty of Medicine,

Department of Infectious Diseases and Clinical Microbiology, Istanbul, Turkey 


\section{INTRODUCTION}

The viral infection of chronic hepatitis B (CHB) is a major public health problem, estimated to affect about 300 million people worldwide ${ }^{1}$. Currently, there is no cure for the CHB infection; however, nucleos(t)ide analogues (NUCs) are used to suppress the viral replication in CHB. The rationale behind long-term viral suppression is that it can be used to reduce progressive liver damage and prevent the development of HBVassociated cirrhosis and hepatocellular carcinoma $(\mathrm{HCC})^{2-4}$. However, data regarding the efficacy of antiviral suppression on cirrhosis and HCC development are scarce and heterogeneous; thus, no firm conclusion can be drawn regarding the benefits of its long-term administration ${ }^{5}$. Further, the challenge of ambiguity regarding the duration of suppression emerges because of the side effects of the drug and the financial burden ${ }^{6}$. Long-term use of NUCs may cause decreases in bone mineral density and glomerular filtration rate in patients and lead to further complications, such as osteomalacia and chronic renal failure ${ }^{7}$. In recent years, to reduce the long-term side effects of viral suppression, discontinuation of antiviral therapy has been suggested by international guidelines ${ }^{8-9}$. The most feared short-term adverse effect of discontinued viral suppression is acute liver failure, which may be induced by virological relapses (VRs) and clinical relapses $(\mathrm{CRs})^{10}$. In this regard, previous studies including cohort studies from different countries, have reported the risk factors associated with VRs and CRs in cases of discontinued therapy ${ }^{11-23}$. However, data from patients who discontinued viral suppression are still limited.

In this study, the short-term clinical and laboratory outcomes following cessation of antiviral therapy were analyzed in patients with $\mathrm{CHB}$ infections.

\section{MATERIAL and METHODS}

\section{Settings and data collection}

This single-center retrospective cohort study took place between January 2016 and July 2019. Data were entered into a Microsoft Access (2010) database. The study protocol was approved by the Ethics Committee of Goztepe Training and Research Hospital at Istanbul Medeniyet University, and the study was conducted in accordance with the principles of the Helsinki Declaration. Informed consent was not required because the research protocol was retrospective.

\section{Patients}

The records of patients who discontinued viral suppression for any reason were retrospectively screened. Patients who had undergone viral suppression for at least two years and had undetectable HBV DNA levels over the last 18 months were included in the study. Patients who were less than 18 years old, pregnants, those who had a co-infection (such as hepatitis C virus, hepatitis D virus, human immunodeficiency virus infections, and/or autoimmune hepatitis), chronic alcoholism, and/or were undergoing immunosuppressive/ chemotherapy were excluded from the study.

\section{Procedures}

Patients were visited monthly for the first three months following cessation of antiviral therapy, and then once every three months for follow-up. At each visit, clinical, biochemical, and virological evaluations for each patient were performed and the data were recorded. Alanine transaminase (ALT, upper limit: $37 \mathrm{U} / \mathrm{L}$ ) (Architect C16000 Abbott Clinic, Abbott Laboratories, North Chicago, IL, USA), Hepatitis B virus DNA (HBV DNA, lower limit of detection: $10 \mathrm{IU} / \mathrm{ml}$ ), $\mathrm{HBs} \mathrm{Ag}$, Anti-HBs, $\mathrm{HBeAg}$, and Anti-HBe (lower limit of detection: $0.05 \mathrm{IU} / \mathrm{mL}$ ) levels were measured. The clinical approach to ALT exacerbation and the decision to initiate oral antiviral therapy were left to the discretion of the specialist. 
Staging of fibrosis according to Ishak classification, was used to evaluate the liver biopsies. Stages 1-2 were classified as mild, 3-4 as moderate, and 5-6 as advanced ${ }^{24}$. The Fibrosis (FIB)-4 score was determined using the following formula: FIB-4 = [age $\times$ AST/platelet count $(109 / \mathrm{L}) \times \sqrt{ }$ ALT $]^{25}$.

\section{Outcomes}

The primary objective of this pre-specified analysis was to compare the characteristics of patients who exhibited a sustained clinical response versus those who experienced a flare-up following the cessation of viral suppression. Clinical response was defined as persistence of post-suppression HBV DNA levels below $2000 \mathrm{IU} / \mathrm{ml}$ and ALT levels lower than twice the normal threshold.

The secondary objective was to compare the characteristics of patients with VR, which was defined by HBV DNA levels above $2000 \mathrm{IU} / \mathrm{ml}$ and ALT levels greater than twice the normal threshold.

\section{Variables and Statistical analysis}

Statistical analysis was conducted using statistical software R (R Foundation for Statistical Computing, Vienna, Austria, 2019). Categorical variables were compared using Pearson's chi-square test or Fisher's exact test, if required. Continuous variables that did not violate normality of distribution were compared using Student's t test; otherwise, they were compared by the Wilcoxon test. The independent factors of age, gender, $\mathrm{HBeAg}$ positivity, platelet (PLT) count, serum albumin level, level of fibrosis on biopsy, and duration of DNA suppression were tested for hazard ratios (HRs).

\section{RESULTS}

In this study, 77 patients were recruited between 2014 and 2019. Table 1 displays the baseline characteristics of the cohort at both the time when the antiviral suppression was initiated (initial) and terminated (baseline). The cohort consisted of
Table 1. Initial (at the start of antiviral suppression) and baseline (at the cessation of antiviral suppression) features of the cohort.

\begin{tabular}{|c|c|c|c|c|}
\hline & $\begin{array}{l}\mathbf{N}=77 \\
\text { Initial }^{1}\end{array}$ & & Baseline & \\
\hline Age & $46.0[38.0 ; 56.0]$ & 77 & & \\
\hline Female gender & $25(32.5 \%)$ & 77 & & \\
\hline $\mathrm{DDU}^{2}$ & $1979[1061 ; 2905]$ & 77 & & \\
\hline $\operatorname{HBeAg}(+)$ & $20(26.7 \%)$ & 75 & $13(17.3 \%)$ & 75 \\
\hline PLT $\left(x 10^{3} / \mathrm{mm}^{3}\right)$ & $207[172 ; 247]$ & 77 & 212 [174;255] & 77 \\
\hline $\operatorname{ALT}(\mathrm{U} / \mathrm{L})$ & $45.0[24.0 ; 89.0]$ & 77 & $20.0[15.0 ; 30.0]$ & 77 \\
\hline HDL (U/L) & $40.0[36.5 ; 44.0]$ & 7 & $44.0[36.5 ; 48.5]$ & 7 \\
\hline Cholesterol (U/L) & 176 [160;199] & 57 & $181[163 ; 199]$ & 57 \\
\hline LDL (U/L) & $126[110 ; 148]$ & 23 & $126[102 ; 145]$ & 23 \\
\hline Triglyceride (U/L) & 103 [75.0; 174] & 13 & $134[81.0 ; 176]$ & 13 \\
\hline \multirow{3}{*}{$\begin{array}{l}\text { Fibrosis }^{3} \\
\text { moderate } \\
\text { severe }\end{array}$} & \multirow{3}{*}{\multicolumn{2}{|c|}{68}} & & \multirow[t]{3}{*}{7} \\
\hline & & & & \\
\hline & & & $1(14.3 \%)$ & \\
\hline \multicolumn{3}{|l|}{ FIB 4 score } & & \multirow[t]{3}{*}{77} \\
\hline$[\overline{0}-1]$ & - & & $65(84.4 \%)$ & \\
\hline$[2-3]$ & - & & $12(15.6 \%)$ & \\
\hline \multirow{4}{*}{$\begin{array}{l}\mathrm{HAI}^{4} \\
\quad \text { mild } \\
\text { moderate } \\
\text { severe }\end{array}$} & & \multirow[t]{4}{*}{68} & & \multirow[t]{4}{*}{67} \\
\hline & $40(58.8 \%)$ & & $41(61.2 \%)$ & \\
\hline & $17(25.0 \%)$ & & $14(20.9 \%)$ & \\
\hline & $3(4.41 \%)$ & & $3(4.48 \%)$ & \\
\hline
\end{tabular}

${ }^{1}$ Initial, at the time antiviral suppression started; Baseline, at the time antiviral suppression terminated

${ }^{2} D D U$, duration of DNA suppression (days)

${ }^{3}$ Fibrosis, mild $=0-2$, moderate $=3-4$, severe $=5-6$

${ }^{4} \mathrm{HAI}$, mild $=$

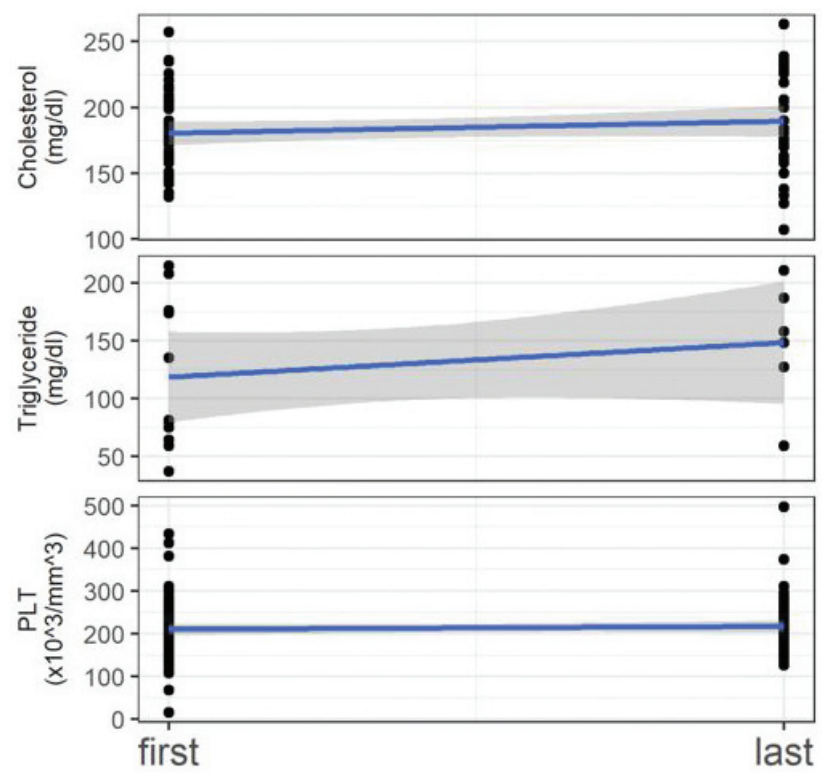

Figure 1. The mean platelet, cholesterol, and triglyceride blood levels of CHB patients under antiviral suppression. 

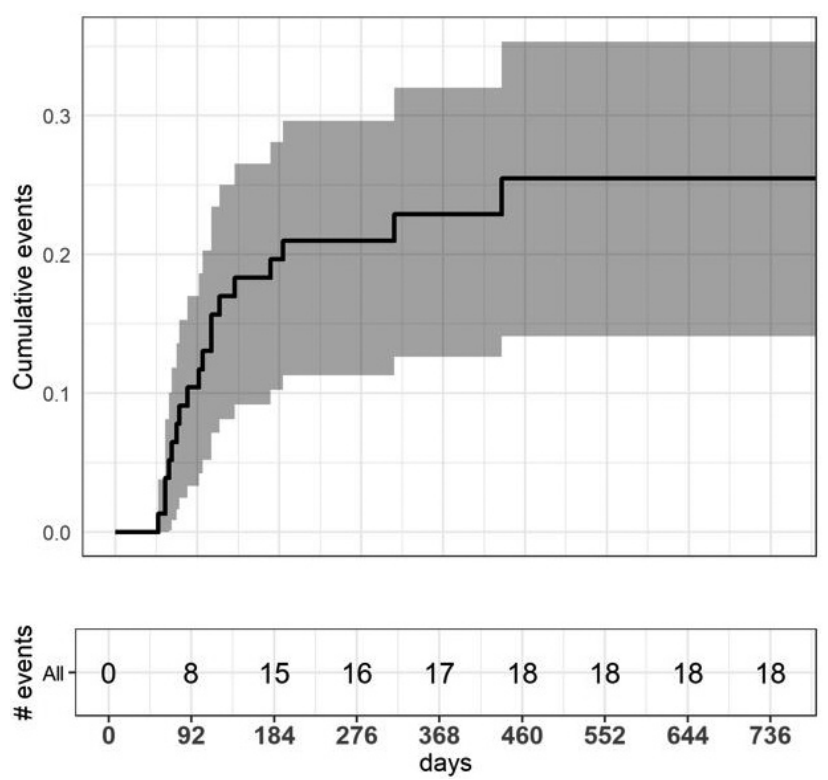

Figure 2. The cumulative incidence of clinical relapse after antiviral treatment was stopped.

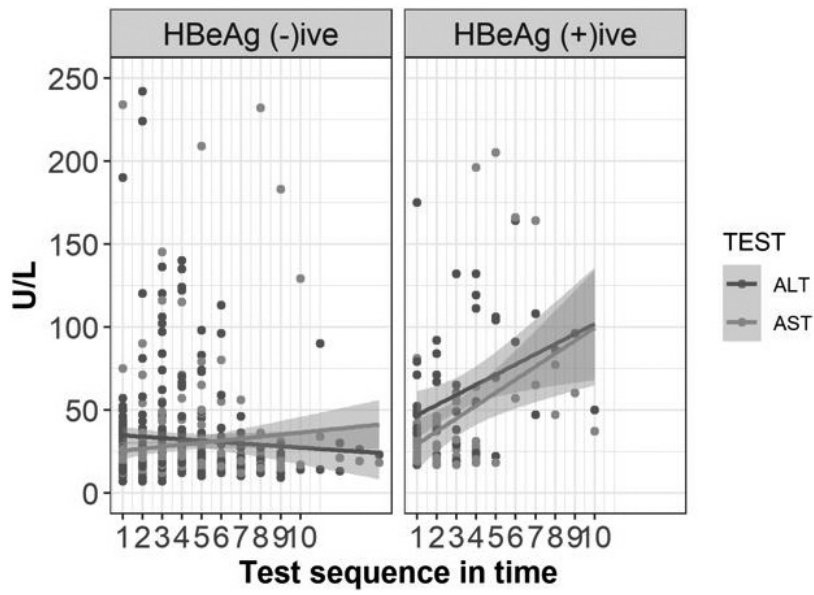

Figure 3. Transaminase levels in $\mathrm{HBeAg}(+)$ and $\mathrm{HBeAg}(-)$ patients during the follow-up.

25 (32.5\%) female patients with a median age of 46 years (interquartile range (IQR) 38.0; 56.0). At baseline, the patients had undetectable HBV DNA levels (less than $29 \mathrm{IU} / \mathrm{mL}$ ), and the mean suppression time was 1979 days [IQR 1061; 2905]. The mean ALT level was 20.0 IU/L [IQR 15.0; 30.0] at baseline. HBeAg status at baseline showed that $9.4 \%$ of the patients underwent $\mathrm{HBeAg}$ seroconversion with NUCs. Figure 1 displays cholesterol, triglyceride, and PLT values at the initial and baseline time-points. Although there was a slight increase in the triglyceride levels,

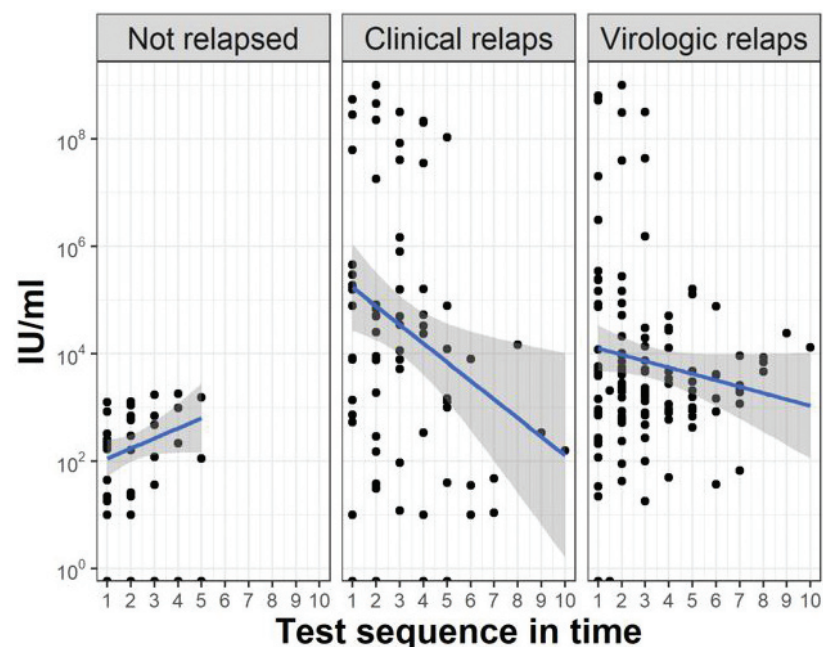

Figure 4. Relationship between HBV DNA levels and virological and clinical relapses with no events.

these three factors stayed relatively stable during the suppression period. In other words, NUCs were generally well-tolerated by the patients.

During the cessation of viral suppression (CAS period), four patients underwent $\mathrm{HBsAg}$ seroconversion, and one patient developed seroclearance. All of these five patients [incl. $4(80 \%)$ males] were $\mathrm{HBeAg}$ negative with a mean age of $57 \pm 12$ years. Approximately $23.4 \%$ (18/77) of patients experienced CR and $40 \%$ (31/77) experienced VR.

Figure 2 displays CR as cumulative events by time. The mean onset time of CR was 451 (SD, 382; range $48-1930$ ) days. Nearly $80 \%$ of 18 patients achieved $\mathrm{CR}$ within the first six months. The mean time to the onset of VR was 615 (SD, 387; range 215-1930) days. Accordingly, we may expect VR only if a patient does not have CR in the first six months of the CAS period.

Liver enzyme levels of $\mathrm{HBeAg}(-)$ patients stayed relatively stable during the CAS period, whereas liver enzymes of $\mathrm{HBeAg}(+)$ patients displayed a tendency to decline over time (Figure 3). However, no patients experienced hepatic failure, and none died during the study period.

Figure 4 displays the HBV DNA levels of the 
Table 2. HRs of key variables for clinical relapse.

\begin{tabular}{|c|c|c|c|c|}
\hline & $\begin{array}{l}\text { No event } \\
\mathrm{N}=59\end{array}$ & $\begin{array}{l}\text { Event } \\
\mathrm{N}=18\end{array}$ & HR & p-value \\
\hline Age & $47.0[38.0 ; 54.0]$ & $45.0[38.2 ; 57.0]$ & $1.00[0.97 ; 1.04]$ & 0.883 \\
\hline Female gender & $19(32.2 \%)$ & $6(33.3 \%)$ & $1.06[0.40 ; 2.83]$ & 0.905 \\
\hline ALT & $20.0[14.5 ; 30.0]$ & $19.5[15.2 ; 32.8]$ & $1.00[0.97 ; 1.04]$ & 0.968 \\
\hline PLT & 212 [177;256] & $201[170 ; 242]$ & 0.99 [0.99;1.00] & 0.247 \\
\hline HBeAg (+)ive & $9(15.8 \%)$ & $4(22.2 \%)$ & $1.45[0.48 ; 4.42]$ & 0.505 \\
\hline Albumin & $4.40[4.20 ; 4.53]$ & $4.45[4.18 ; 4.55]$ & $0.53[0.21 ; 1.32]$ & 0.175 \\
\hline Fibrosis & $8(13.6 \%)$ & $4(22.2 \%)$ & $1.67[0.55 ; 5.08]$ & 0.360 \\
\hline \multicolumn{5}{|l|}{ FIB_4 } \\
\hline$[0-\overline{1}]$ & $51(78.5 \%)$ & $14(21.5 \%)$ & Ref. & 0.360 \\
\hline$[2-3]$ & $8(66.7 \%)$ & $4(33.3 \%)$ & $1.67[0.55 ; 5.08]$ & \\
\hline $\operatorname{DDU}^{5}($ mean $(\mathrm{SD}))$ & 2138 (1429) & $2134(1438)$ & $1[1 ; 1]$ & 0.923 \\
\hline
\end{tabular}

${ }^{5} \mathrm{DDU}$, duration of DNA suppression (days)

patients in three subsets as follows: the patients that did not relapse, patients who achieved CR, or VR. HBV DNA levels declined over time in the patients with CR. Table 2 presents the univariate HRs of CR risk. Since none of the tested variables had a significant $H R$, no predictors could be identified among them.

$\mathrm{HBeAg}$ reversion was observed in four $(31 \%)$ patients. Severe hepatitis was reported in two (4\%) of 77 patients after CAS. One patient showed an increased serum bilirubin level $(11 \mathrm{mg} / \mathrm{dL}$ [range; $0.2-1.1 \mathrm{mg} / \mathrm{dl}]$ ), along with an elevation in ALT concentration to $1700 \mathrm{U} / \mathrm{L}$ (range 0-42 $\mathrm{U} / \mathrm{L}$ ) and evidence for nodular involvement of the bilateral suprarenal gland on positron emission tomography-computed tomography. Severe hepatitis resolved after treatment was restarted. None of the patients with CR showed clinical or biological signs of hepatic decompensation, and no patient died after CAS.

\section{DISCUSSION}

NUCs inhibit HBV reverse transcription activity and do not affect covalently closed circular DNA (cccDNA), which provides a minichromosomal template for replication ${ }^{26}$. HBV replication can resume after termination or interruption of the NUCs with cccDNA transcription. Therefore, the finite approach to chronic HBV treatment with NUCs still requires further research and development, and the use of this method for disease management remains controversial. The main reason for the lifelong antiviral treatment recommendation for $\mathrm{CHB}$ patients is that the risk of developing cirrhosis and HCC without viral DNA suppression may be higher. Reducing cost burden, enhancing patient adherence, and minimizing long-term drug toxicity are the main motivators for clinicians to terminate NUC usage, while a flare-up of severe hepatitis resulting in acute liver failure is the main potential risk.

In a large-scale prospective cohort study with $\mathrm{HBsAg}(+)$ individuals, only about $10 \%$ of the patients developed cirrhosis and $\mathrm{HCC}^{27}$. Furthermore, other risk factors like fatty liver disease have been reported as major contributors to the progression of hepatitis into cirrhosis ${ }^{28}$. Other factors, including aging and metabolic changes, may also be confounders that influence the emergence of of unfavorable outcomes during treatment with NUCs. A retrospective study was performed on $\mathrm{HBV}$ patients administered entecavir or tenofovir-disoproxil-fumarate, administration of tenofovir-disoproxil-fumarate, but not entecavir was associated with decreased serum cholesterol levels ${ }^{29}$. On the contrary, patients in the present study showed an increased mean triglyceride level, while their cholesterol levels remained stable. In the long-term, further research is needed 
to identify whether this increase in triglyceride levels creates any additional risk.

Additionally, NUCs do not produce antifibrotic effects alone. In this study, no significant change was observed between initial fibrosis and FIB-4 scores before CAS. In a 144-week cohort study that compared NUCs alone with NUCs plus an antifibrotic agent, the combination therapy resulted in more profound antifibrotic effects ${ }^{30}$. As in the case of cirrhosis, the relationship between $\mathrm{HCC}$ and $\mathrm{HBV}$ is debatable. Aflatoxin exposure as a major confounding factor for HCC development was not investigated in a well-known HCC epidemiological study ${ }^{31}$. Although the details are beyond the scope of this article, the findings reported in a recently published proteomics and genomics study have raised suspicions about the etiology of $\mathrm{HCC}^{32}$. In the present study, $23 \%$ of the patients experienced CR after discontinuation of NUC treatment. Among them, two patients (2\%) developed severe hepatitis. One observational study revealed association between pretreatment cirrhosis and liver failure. The initial fibrosis (moderate-severe) score was not associated with CR. However, a second biopsy before CAS was not possible due to its invasive nature. FIB-4 scores were also not associated with CR.

Although HBV DNA monitoring after CAS was recommended as a predictor or follow-up parameter for biochemical exacerbation, the findings of current study did not support this method ${ }^{11}$. On the contrary, CR presenting with a decrease in HBV DNA, as in acute hepatitis B, is differentiated from chronic hepatitis $B$ with an acute exacerbation ${ }^{33}$. In a systematic review of 25 studies and 2332 patients, HBeAg positivity was associated with VR. In this study, HBeAg positivity was not associated with $\mathrm{CR}^{34}$. However, both HBV DNA and HBeAg were associated with true replication sourced from HBV pregenomic RNA (pgRNA) and were proposed as markers of cccDNA activity, and CR may be related to host inflammatory factors ${ }^{35}$.
Some observational studies reported that HBsAg seroconversion developed in 8-15\% of the patients after treatment cessation ${ }^{36,37}$. In comparative studies, it was noted that $\mathrm{HBsAg}$ clearance was higher in patients with NUC discontinuation compared with the control group ${ }^{11,38}$. Although the follow-up period was an important confounding factor, it is noteworthy in this study that HBsAg seroclearance was observed in five patients over a short time period. In a systematic review, the pooled annual rate of HBsAg seroclearance in $19 \mathrm{CHB}$ patients was reported to be $1.02 \%{ }^{39}$. The authors indicated that $\mathrm{HBsAg}$ seroclearance was greater in $\mathrm{HBeAg}(-)$ patients, irrespective of their antiviral regimes. Likewise, all patients were $\mathrm{HBeAg}(-)$, and $\mathrm{HBsAg}$ seroclearance was not associated with treatment history in this study. Although NUCs are thought to exert a different effect by providing interferon release in peripheral blood cells, a drug-specific condition for both $\mathrm{CR}$ and HbsAg seroclearance could not be identified ${ }^{40}$. Researchers have claimed that changes in natural (CD56dim NK cells) and adaptive (Th17/Treg balance) immunity after suppression of viral replication might play a role in the pathogenesis of seroclearance ${ }^{41}$. The role of immunity in determining the seroclearance process warrants further investigation.

The participants in this study accurately represented the relevant population and possessed the general characteristics of the patients with $\mathrm{CHB}$ infections undergoing treatment. However, most of the patients had mild to moderate baseline fibrosis, which limited the study's ability to evaluate the patients with advanced fibrosis. In addition, routine genotypic analysis and $\mathrm{HBsAg}$ quantitation were not performed. However, epidemiological studies in Turkey revealed that more than $90 \%$ of the patients had HBV genotype $\mathrm{D}^{42}$.

In conclusion, considering the limited number of patients in this study, no significant benefits were found regarding the discontinuation of antiviral 
therapy after viral suppression in patients with initially severe fibrotic HBV infection. For patients with mild to moderate fibrosis, cessation of antiviral therapy was not associated with adverse outcomes.

\section{REFERENCES}

1. Trépo C, Chan HLY, Lok A. Hepatitis B virus infection. Lancet. 2014;384:2053-63. [CrossRef]

2. Buti M, Tsai N, Petersen J, et al. Seven-year efficacy and safety of treatment with tenofovir disoproxil fumarate for chronic hepatitis B virus infection. Dig Dis Sci. 2015;60:1457-64. [CrossRef]

3. Kim WR, Loomba R, Berg T, et al. Impact of longterm tenofovir disoproxil fumarate on incidence of hepatocellular carcinoma in patients with chronic hepatitis B. Cancer 2015;121:3631-8. [CrossRef]

4. Marcellin P, Gane E, Buti M et al. Regression of cirrhosis during treatment with tenofovir disoproxil fumarate for chronic hepatitis B: a 5-year open-label follow-up study. Lancet. 2013;381:468-75. [CrossRef]

5. Lok ASF, McMahon BJ, Brown RS, et al. Antiviral therapy for chronic hepatitis B viral infection in adults: A systematic review and meta-analysis. Hepatology. 2016;63:284306. [CrossRef]

6. Nayagam S, Sicuri E, Lemoine $M$, et al. Economic evaluations of HBV testing and treatment strategies and applicability to low and middle-income countries. BMC Infect Dis. 2017;17:692. [CrossRef]

7. Hsu Y-C, Wei MT, Nguyen MH. Tenofovir alafenamide as compared to tenofovir disoproxil fumarate in the management of chronic hepatitis B with recent trends in patient demographics. Expert Rev Gastroenterol Hepatol. 2017;11:999-1 [CrossRef]

8. Sarin SK, Kumar M, Lau GK, et al. Asian-Pacific clinical practice guidelines on the management of hepatitis $B$ : a 2015 update. Hepatol Int. 2016;10:1-98. [CrossRef]

9. European Association for the Study of the Liver. EASL 2017 Clinical Practice Guidelines on the management of hepatitis B virus infection. J Hepatol. 2017;67:370-98. [CrossRef]

10. Van Hees S, Bourgeois S, Van Vlierberghe $\mathrm{H}$, et al. Stopping nucleos(t)ide analogue treatment in Caucasian hepatitis B patients after $\mathrm{HBeAg}$ seroconversion is associated with high relapse rates and fatal outcomes. Aliment Pharmacol Ther. 2018;47:1170-80. [CrossRef]

11. Berg T, Simon K-G, Mauss S, et al. Long-term response after stopping tenofovir disoproxil fumarate in noncirrhotic HBeAg-negative patients - FINITE study. J Hepatol. 2017;67:918-24. [CrossRef]

12. Cao J, Chi H, Yu T, et al. Off-treatment hepatitis b virus (hbv) dna levels and the prediction of relapse after discontinuation of nucleos(t)ide analogue therapy in patients with chronic hepatitis b: a prospective stop study. J Infect Dis. 2017;215:581-9. [CrossRef]

13. Chen C-H, Hsu Y-C, Lu S-N, et al. The incidence and predictors of $\mathrm{HBV}$ relapse after cessation of tenofovir therapy in chronic hepatitis B patients. J Viral Hepat. 2018;25:590-7. [CrossRef]

14. Chi H, Wong D, Peng J, et al. Durability of response after hepatitis b surface antigen seroclearance during nucleos $(t)$ ide analogue treatment in a multiethnic cohort of chronic hepatitis b patients: results after treatment cessation. Clin Infect Dis. 2017;65:680-3. [CrossRef]

15. Fan R, Zhou B, Xu M, et al. Association between negative results from tests for hbv dna and rna and durability of response after discontinuation of nucles(t)ide analogue therapy. Clin Gastroenterol Hepatol. 2019;18:719-27. [CrossRef]

16. Höner zu Siederdissen C, Rinker F, Maasoumy B, et al. Viral and host responses after stopping long-term nucleos (t) ide analogue therapy in $\mathrm{HBeAg}$-negative chronic hepatitis B. J Infect Dis. 2016;214:1492-7. [CrossRef]

17. Hung C-H, Wang J-H, Lu S-N, et al. Hepatitis B surface antigen loss and clinical outcomes between $\mathrm{HBeAg-}$ negative cirrhosis patients who discontinued or continued nucleoside analogue therapy. J Viral Hepat. 2017;24:599607. [CrossRef]

18. Jeng W-J, Chen Y-C, Chien R-N, Sheen I-S, Liaw Y-F. Incidence and predictors of HBsAg seroclearance after cessation of nucleos(t)ide analogue therapy in $\mathrm{HBeAg}$ negative chronic hepatitis B: HBsAg loss after stopping Nuc therapy in $\mathrm{HBeAg}$ negative chronic hepatitis $B$. Hepatology. 2017;68:425-34. [CrossRef]

19. Jung KS, Park JY, Chon YE, et al. Clinical outcomes and predictors for relapse after cessation of oral antiviral treatment in chronic hepatitis B patients. J Gastroenterol. 2016;51:830-9. [CrossRef]

20. Liu F, Wang L, Li XY, et al. Poor durability of lamivudine effectiveness despite stringent cessation criteria: A prospective clinical study in hepatitis $B$ e antigen-negative chronic hepatitis B patients: Durability of lamivudine in HBeAg-CHB. J Gastroenterol Hepatol. 2011;26:456-60. [CrossRef]

21. Pan H-Y, Pan H-Y, Chen L, et al. Ten-year follow-up of hepatitis $\mathrm{B}$ relapse after cessation of lamivudine or telbivudine treatment in chronic hepatitis B patients. Clin Microbiol Infect. 2015;21:1123.e1-e9. [CrossRef]

22. Nagata N, Kagawa T, Hirose S, et al. Off-treatment durability of antiviral response to nucleoside analogues in patients with chronic hepatitis B. BMC Gastroenterol. 2016;16:38. [CrossRef]

23. Yao C-C, Hung C-H, Hu T-H, et al. Incidence and predictors of $\mathrm{HBV}$ relapse after cessation of nucleoside analogues in HBeAg-negative patients with $\mathrm{HBsAg} \leq 200 \mathrm{IU} / \mathrm{mL}$ Sci Rep. 2017;7:1839. [CrossRef]

24. Ishak K, Baptista A, Bianchi L, et al. Histological grading and staging of chronic hepatitis. J Hepatol. 1995;22:696-9. [CrossRef]

25. Kim BK, Kim DY, Park JY, et al. Validation of FIB-4 and comparison with other simple noninvasive indices for predicting liver fibrosis and cirrhosis in hepatitis B virusinfected patients. Liver Int. 2010;30:546-53. [CrossRef]

26. Allweiss L, Dandri $M$. The role of cccDNA in HBV maintenance. Viruses. 2017;9:156. [CrossRef]

27. Si J, Yu C, Guo Y, et al. Chronic hepatitis B virus infection and risk of chronic kidney disease: a population-based prospective cohort study of 0.5 million Chinese adults. BMC Med. 2018;16:93. [CrossRef]

28. Choi HSJ, Brouwer WP, Zanjir WMR, et al. Non-Alcoholic steatohepatitis is associated with liver-related outcomes and all-cause mortality in chronic hepatitis B. Hepatology. 2019;71:539-48. [CrossRef]

29. Suzuki K, Suda G, Yamamoto Y, et al. Tenofovir-disoproxil- 
fumarate modulates lipid metabolism via hepatic CD36/ PPAR-alpha activation in hepatitis B virus infection. J Gastroenterol. 2020;56:168-80. [CrossRef]

30. Zhou Y, Hu C, Yuan G, et al. Antiviral and antifibrotic therapies reduce occurrence of hepatocellular carcinoma in patients with chronic hepatitis B and liver fibrosis: a 144-week prospective cohort study. Nan Fang Yi Ke Da Xue Xue Bao. 2019;39:633-40. [CrossRef]

31. Beasley RP, Hwang LY, Lin CC, et al. Hepatocellular carcinoma and hepatitis B virus. A prospective study of 22 707 men in Taiwan. Lancet. 1981;2:1129-33. [CrossRef]

32. Gao Q, Zhu H, Dong L, et al. Integrated proteogenomic characterization of HBV-related hepatocellular carcinoma. Cell. 2019;179:561-77.e22. [CrossRef]

33. Chang M-L, Liaw Y-F. Hepatitis B flares in chronic hepatitis B: pathogenesis, natural course, and management. J Hepatol. 2014;61:1407-17. [CrossRef]

34. Papatheodoridis G, Vlachogiannakos I, Cholongitas E, et al. Discontinuation of oral antivirals in chronic hepatitis B: A systematic review. Hepatology. 2016;63:1481-92. [CrossRef]

35. Butler EK, Gersch J, McNamara A, et al. Hepatitis B virus serum DNA and RNA levels in nucleos(t)ide analogtreated or untreated patients during chronic and acute infection. Hepatology. 2018;68:2106-17. [CrossRef]

36. Ha M, Zhang G, Diao S, et al. A prospective clinical study in hepatitis B e antigen-negative chronic hepatitis
B patients with stringent cessation criteria for adefovir. Arch Virol. 2012;157:285-90. [CrossRef]

37. Papatheodoridis GV, Manolakopoulos S, Su T-H, et al. Significance of definitions of relapse after discontinuation of oral antivirals in HBeAg-negative chronic hepatitis B. Hepatology. 2018;68:415-24. [CrossRef]

38. Liu F, Liu ZR, Li T, et al. Varying 10-year off-treatment responses to nucleos $(\mathrm{t})$ ide analogues in patients with chronic hepatitis B according to their pretreatment hepatitis B e antigen status. J Dig Dis. 2018;19:561-71. [CrossRef]

39. Yeo YH, Ho HJ, Yang H-I, et al. Factors associated with rates of $\mathrm{HBsAg}$ seroclearance in adults with chronic HBV infection: A systematic review and meta-analysis. Gastroenterology. 2019;156:635-46.e9. [CrossRef]

40. Murata K, Asano M, Matsumoto A, et al. Induction of IFN$\lambda 3$ as an additional effect of nucleotide, not nucleoside, analogues: a new potential target for HBV infection. Gut 2018;67:362-71. [CrossRef]

41. Liu N, Liu B, Zhang L, et al. Recovery of circulating CD56dim NK cells and the balance of Th17/Treg after nucleoside analog therapy in patients with chronic hepatitis B and low levels of HBsAg. Int Immunopharmacol. 2018;62:5966. [CrossRef]

42. Atalay MA, Gokahmetoglu S, Aygen B. Genotypes of hepatitis B virus in Central Anatolia, Kayseri, Turkey. Saudi Med J. 2011;32:360-3. PMID: 21483993. 